\title{
Characterization of Union Sites for Opioids in Human Lymphocyte Membranes
}

\author{
Carlos Osvaldo Navarro Venegas* and Luis Alberto Raggi Saini \\ Department of Preventive Animal Medicine, University of Chile, Chile \\ *Corresponding author: Carlos Osvaldo Navarro Venegas, Department of Preventive Animal Medicine, Faculty of Veterinary and \\ Animal Sciences (FAVET), University of Chile, Santa Rosa, 11735, Santiago, Chile.
}

To Cite This Article: Carlos Osvaldo Navarro Venegas. Characterization of Union Sites for Opioids in Human Lymphocyte Membranes. Am J Biomed Sci \& Res. 2019 - 4(4). AJBSR.MS.ID.000803. DOI: 10.34297/AJBSR.2019.04.000803

Received: July 24, 2019 | Published: August 02, 2019

\begin{abstract}
The opioid peptides Methionine enkephalin and $\beta$-Endorphin are stimulators of Natural Killer cytolytic activity. To know the biochemical mechanisms that explain this action, the binding of Methionine enkephalin and Naloxone in presence or ausence of $\mathrm{Na}^{+}$ion and GTP to human Lymphocyte membranes was characterized.
\end{abstract}

Methionine enkephalin or $\beta$-Endorphin in concentrations greater than physiological concentrations delivers stimulations of the order of $25 \%$ on the respective control value. For the receptors, a binding assay of the radioligands $\left({ }^{3} \mathrm{H}\right)$-Methionine enkephalin and $\left({ }^{3} \mathrm{H}\right)$-Naloxone was used, with the Scatchard analysis finding only one type of binding site in each case, with $\mathrm{K}_{\mathrm{D}}$ values of 6.8 and 5.9 [nm] and $\mathrm{B}_{\max }$ of 38 and 54 [fmol/mg of protein] respectively. These values are not comparable to those described in nervous, tumor or lymphoid tissue. The displacement tests revealed similarity between Naloxone and Methionine enkephalin binding sites due to their mutual displacement, unlike that observed with $\beta$-Endorphin.

In contrast to previous studies, it was found that the effect of the $\mathrm{Na}^{+}$ion $(100 \mathrm{mM})$ did not modify the IC50 values, whereas GTP markedly reduced the total binding of both ligands: Methionine enkephalin and Naloxone and suggests the participation of a protein with G protein characteristics.

Keywords: Methionine Enkephalin; B-Endorphin; Natural Killer Cells; Naloxone; Human Lymphocyte Membranes; Na+ Ion; GTP; Displacement Assays

\section{Introduction}

Our immune system has diverse defense mechanisms that can be classified as a humoral and cellular responses, that is, the production of diversity of antibodies by the a B Lymphocyte and others cells capable of recognizing and destroying other cells such as Natural Killer (NK) cells, which constitute a subpopulation of lymphocytes with the ability to destroy tumoral or viral infected cells, without prior sensitization or restriction of the Histocompatibility Major Antigen type. The NK cells correspond morphologically to large granular lymphocytes and represent a minor but important proportion of total circulating mononuclear cells [1,2].

This Natural Killer Cell Activity (NKCA) which decreases markedly in pathologies such as leukemia, immunodeficiency and sepsis $[2,3]$ has been the subject of extensive research in recent years, evidencing the existence of several modulators such as several lymphokines, especially IL- 2 and IFN $(\alpha, \beta, \gamma)[4,5]$ which promote either the proliferation of NK cells and/or their stimulation $[6,7]$.

Another important group of modulators are the opioid peptides (OP), particularly the enkephalins and endorphins: Methionine enkephalin (ME), Leucine enkephalin (LE) and $\beta$-Endorphin (BE) $[8,9]$.

In humans, BE biosynthesis begins when its $\beta$-Lipotrophin precursor is co-incubated with the adrenocorticocotrophin hormone (ACTH), from the cutaneous proopiomelane (POMC) in the corticotrophs of the anterior pituitary gland, then generating $\gamma$ - Lipotrophin and BE. Because $\beta$-Lipotrophin is secreted intact, BE levels are extremely low. However, agents that stimulate the release of ACTH, including hypoglycemia and intense exercise also increase the plasma concentration of $\mathrm{BE}[10,11]$. The enkephalins derived from Proenkephalin A are stored in the adrenal medulla and subsequently released in response to hypoglycemia or renal failure $[12,13]$. In several species studied they are an important part of the adrenomodular chromaffin granules, mainly in the form of pentapeptides $[14,15]$. In addition to the actions described for OP, such as the inhibition of the growth of some types of tumors and participation in the control of brain development $[16,17]$, these exert multiple effects on the cells of the Immune system: 
a. In T cells, both peptides decrease antigen-specific cytolysis $[18,19]$.

b. In polymorphonuclear leukocytes, ME stimulates chemotaxis [20], while BE stimulates adhesion to surfaces [20] and the production of superoxides [21,22]

c. In monocytes stimulation of chemotaxis and inhibition of phagocytosis has been described, by ME, LE and BE [23,24].

d. In NK cells, it has been described that these three endogenous peptides stimulate cytolytic activity [8] O'Connor et al., 2006).

Receptors for opioids have been described in the nervous system and peripheral tissues $[25,26]$ and opioid binding sites have been detected in a wide variety of animal and human tumors $[27,28]$. It is known that the actions of opioids in the nervous system are mediated by at least four different receptor types $(\mu, \delta, \kappa$, $\sigma)$ each of these with ligand selectivity, distribution and different physiological effects [26]. In the IS the existence of binding sites for these neuropeptides has been controversial $[29,30]$.

Binding sites have been described in human T lymphocytes using the antagonist Naloxone [12,31] and in human and murine leucocytes [32,33], reaffirming the existence of receptors with opioid characteristics [34,35].

Considering the existence of opioid receptors in that would explain the interconnection in nervous/immune system, in this work has been studied and partially characterized the binding sites present in human lymphocyte membranes (HLM) both for the pentapeptide ME due to its possible relationship with the increase of NKCA, as well as for the opiate antagonist Naloxone, capable of reversing this action $[17,26]$

\section{Materials and Methods}

\section{Lymphocytes}

Obtained from peripheral blood samples from healthy voluntary donors from the blood bank of the José Joaquín Aguirre Hospital of the University of Chile. Cells from the K-562 cell line, derived from human erythroleukemia, were used as target cells.

\section{Culture and maintenance of target cells}

The growth and maintenance of the K-562 cell line RPMI-1640 was added bovine fetal serum (FBS) at a final concentration of $10 \%$ and was supplemented with antibiotics and antifungals: $100 \mathrm{U} / \mathrm{mL}$ penicillin, $100 \mu \mathrm{g} / \mathrm{mL}$ Streptomycin, $1.25 \mu \mathrm{g} / \mathrm{mL}$ Fungizone (complete culture medium: CCM). Cell vitality was followed by exclusion of the trypan blue dye. Radiomarking of target cells. K-562 cells $\left(10^{6}\right.$ cells $\left./ \mathrm{mL}\right)$ were incubated in the presence of $100 \mu \mathrm{Ci}$ of sodium chromate $\left({ }^{51} \mathrm{Cr}\right.$; Chilean Nuclear Energy Commission) for one hour at $37^{\circ} \mathrm{C}$ with occasional shaking every fifteen minutes. After the deadline, the cells are washed three times with CCM, finally adjusting to a concentration of $5 \times 10^{4}$ cells $/ \mathrm{mL}$ of CCM. The target cells thus obtained were used immediately in the NKCA assays.

Obtaining lymphocytes (effector cells) [36]. The heparinized blood sample, approximately $40 \mathrm{~mL}$, is divided into $50 \mathrm{~mL}$ conical plastic tubes. To each fraction is added $6.8 \mathrm{~mL}$ of a solution composed of dextran (3\%) and $\mathrm{NaCl}(0.9 \%)$, inverting the tube three times and leaving it to rest for 30 minutes at room temperature. The supernatant is transferred to another conical tube with the same characteristics. Then, $27 \mathrm{~mL}$ of Ficoll-Hypaque solution ( $\mathrm{d}=1.077)$ (Sigma Chemicals Co. (St. Louis MO USA) are added and the tubes are centrifuged at $500 \mathrm{xg}$ for 15 minutes at room temperature. The layer of cells formed in the interface is extracted and transferred to $15 \mathrm{~mL}$ glass tubes. Cells were washed with $10 \mathrm{~mL}$ of PBS solution $\left(15 \mathrm{mM} \mathrm{KH}_{2} \mathrm{PO}_{4}, 8 \mathrm{mM} \mathrm{Na}_{2} \mathrm{HPO}_{4}, 3 \mathrm{mM} \mathrm{KCl}, 140 \mathrm{mM} \mathrm{NaCl}, 5 \mathrm{mM}\right.$ $\mathrm{MgCl}_{2}$ and $150 \mu \mathrm{M} \mathrm{CaCl}_{2}$ ) centrifuged at $250 \mathrm{xg}$, for 3 minutes at room temperature and repeating twice the washed. Finally, the cells were resuspended in CCM at a concentration of $2 \times 10^{6}$ cells $/ \mathrm{mL}$ and used immediately in the cytolysis assays.

\section{Treatment of effector cells with neuropeptides}

The effector cells were incubated with ME and BE. Thus, lymphocytes $\left(2 \times 10^{6}\right.$ cells $\left./ \mathrm{mL}\right)$ were preincubated in Eppendorf tubes in the presence of ME $\left(10^{-6}-10^{-10} \mathrm{M}\right)$ or BE $\left(10^{-8}-10^{-12} \mathrm{M}\right)$. The lymphocytes were centrifuged at $250 \mathrm{xg}$ for three minutes and resuspended in CCM and the centrifugation is repeated. Finally, the cells are resuspended and adjusted to a concentration of $2 \times 10^{6}$ cells $/ \mathrm{mL}$ in CCM and the cytolysis assay is carried out. Lymphocytes incubated only in CCM are used as control. All the stimulation tests were performed with an effector: target ratio of 40 (40:1).

\section{NKCA assay}

To achieve this objective, $0.1 \mathrm{~mL}$ of effector cells $\left(2 \times 10^{6}\right.$ cells/ $\mathrm{mL})$ were added to $0.1 \mathrm{~mL}$ of target cells $\left(5 \times 10^{4}\right.$ cells $\left./ \mathrm{mL}\right)$ in multi-titration plate wells (Nunc), performing this operation in quadruplicate. The plates were centrifuged at $15 \mathrm{xg}$ for 10 minutes and immediately incubated for four hours at $37^{\circ} \mathrm{C}$ and $5 \% \mathrm{CO}_{2}$. Then, the plates were centrifuged again, and $0.1 \mathrm{~mL}$ of this supernatant was analyzed in a gamma counter model Packard Multi-Prias 1 (Packard Instruments Company).

\section{Obtaining of HLM}

Briefly, the effector cells obtained previously according to section 3, were lysed by sonication for ten minutes at room temperature [37]. Then, they were centrifuged at 30,000 $\mathrm{xg}$ for one hour at $4^{\circ} \mathrm{C}$. The precipitate was resuspended in $5 \mathrm{~mL}$ of Tris. $\mathrm{HCl}$ buffer $(50$ mM, pH: 7.7) supplemented with the antibiotic Bacitracin $(50 \mu \mathrm{g} /$ $\mathrm{mL}$ ) and the amount of total proteins present was determined [38].

\section{Radioligand binding assays}

The HLM obtained were used in binding of 3H-ME and 3H-Naloxone Ogawa et al [39] (Amersham (UK, $49.4 \mathrm{Ci} / \mathrm{mmol}$ and $40 \mathrm{Ci}$ / mmol, respectively) which comprises incubating the membranes in Eppendorf tubes (250 ug protein per assay) for 30 minutes in increasing concentrations of radioligand (1-40 nM) in volume of 150 $\mathrm{uL}$ and $25^{\circ} \mathrm{C}$ with constant agitation The reaction is terminated by dilution at $4^{\circ} \mathrm{C}$ with five $\mathrm{mL}$ of the Tris.HCL buffer and immediate vacum filtration. The filters (GF/C Whatman) are washed twice with five $\mathrm{mL}$ of same buffer and once dry the retained radioactivity determined in them by a liquid scintillation counter, model Delta 300 (Searle Analytic Inc.) having 40\% of efficiency for tritium. The 
total binding corresponds to the radioactivity retained in the filters. In the non-specific binding, incubation was performed in the presence of unlabelled (Naloxone or ME) at a concentration of $10^{-5} \mathrm{M}$. Compound Specific binding was determined by the difference between total and non-specific binding. Thus, the concentration of the bound radioligand (B) is plotted as a function of the concentration of the free radioligand (F), obtaining a saturation curve for the equilibrium reached. Scatchard analysis (1949), which is plotted on the ordinate the values of the ratio $\mathrm{B} / \mathrm{F}$ and the abscissa the value was used to obtain the dissociation constant $\left(\mathrm{K}_{\mathrm{D}}\right)$ and the maximal binding capacity $\left(\mathrm{B}_{\max }\right)$ united radioligand $(\mathrm{B})$. A straight line is obtained whose intersection with the horizontal axis determines the value of $\mathrm{B}_{\max }$ and the negative reciprocal value of the slope corresponds to the value of $\mathrm{K}_{\mathrm{D}}$.

\section{Displacement tests}

Naloxone, ME and BE. Lymphocyte membranes $(250 \mu \mathrm{g}$ of protein per assay) were incubated for 30 minutes at $25^{\circ} \mathrm{C}$ in the Results presence of the radioligand $\left({ }^{3} \mathrm{H}-\mathrm{ME}\right.$ or ${ }^{3} \mathrm{H}-$ Naloxone, $\left.20 \mathrm{nM}\right)$ and the displacer in increasing concentrations $\left(10^{-10}-10^{-2} \mathrm{M}\right)$. Then, both for the end of the reaction and for obtaining the data, which are plotted as percentage of inhibition respect to the control, as a function of the negative value of the logarithm of the concentration of the displacer used and the $\mathrm{IC}_{50}$ values are calculated for each of the displacers. This value corresponds to the concentration of the displeasure capable of inhibiting $50 \%$ of the binding to membranes.

\section{Effect of sodium ions and GTP}

Concentrations of $100 \mathrm{mM}$ and $100 \mu \mathrm{M}$ of $\mathrm{NaCl}$ and GTP were used, respectively, which were added to the incubation medium and then proceeded in the same way described. in the previous section.

\section{Statistical analysis}

The data are expressed as averages, standard error (S.E.M) and analyzed by the paired Student's " $\mathrm{t}$ " test.

\section{Effect of opioids on NKCA}

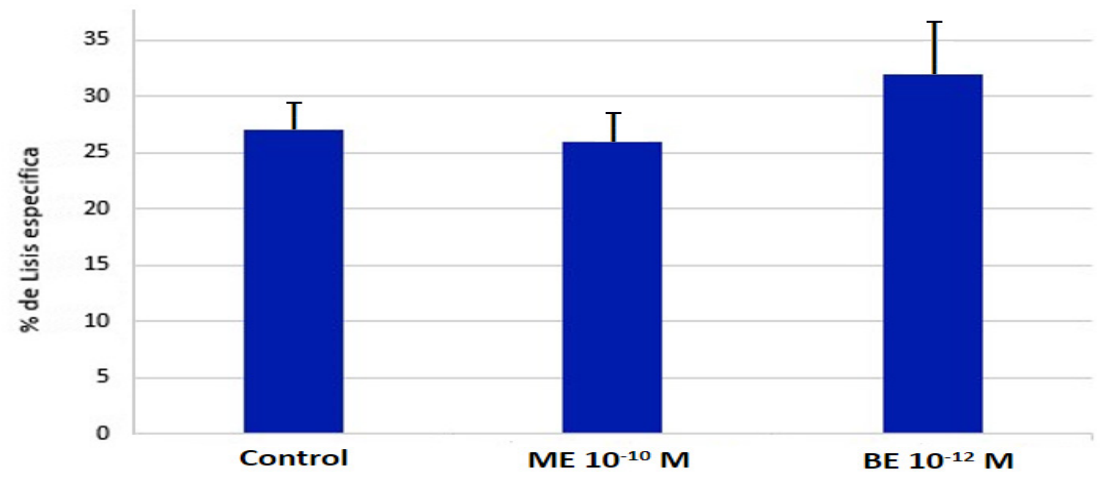

Graphic 1: Effect of OP in physiological concentrations on NKCA. Determinations in quadruplicate $(\mathrm{n}=9)$ ), the stimulation with BE was not significant ( $\mathrm{p}>0.05)$.

The Graphic 1 shows the NKCA stimulation expressed as a percentage of increase over the control value, in the presence of BE and ME in physiological concentrations. The samples treated with BE achieved a stimulation of around $20 \%$ over the control value and only present in $70 \%$ of the samples. The samples incubated in the presence of ME, no stimulation of the NKCA was observed.

The Table 1 show the NKCA in non-physiological concentrations of ME an BE.

\begin{tabular}{|c|c|c|c|c|c|}
\hline \multirow[t]{2}{*}{ AGE/SEX } & \multirow[t]{2}{*}{ CONTROL } & \multicolumn{2}{|c|}{ BE (M) } & \multicolumn{2}{|c|}{ ME (M) } \\
\hline & & $10^{-10}$ & $10^{-8}$ & $10^{-8}$ & $10^{-6}$ \\
\hline $34 / \mathrm{F}$ & 10.8 & 25.5 & 27 & 20.8 & 25.3 \\
\hline $27 / \mathrm{M}$ & 35 & 48 & 51.8 & 40 & 44 \\
\hline $32 / \mathrm{F}$ & 10.5 & 20.1 & 19.7 & 15 & 17.2 \\
\hline $31 / \mathrm{M}$ & 24 & 41.1 & 46.2 & 49.2 & 39.4 \\
\hline $26 / \mathrm{M}$ & 5.3 & 17.2 & 17.4 & 20.6 & 21.9 \\
\hline $35 / \mathrm{M}$ & 15.1 & 19.2 & 19.8 & 18.7 & 20.1 \\
\hline $\mathrm{X} \pm$ S.E.M & $16.8 \pm 4.4$ & $28.5 \pm 5.3$ & $30.3 \pm 6.1$ & $27.4 \pm 5.6$ & $28.0 \pm 4.5$ \\
\hline \multicolumn{2}{|c|}{ GROUP B } & & & & \\
\hline $36 / F$ & 30 & 38 & 34 & 35 & 17.2 \\
\hline $26 / \mathrm{M}$ & 11.6 & 13.3 & 10.4 & 16 & 17.4 \\
\hline
\end{tabular}




\begin{tabular}{|c|c|c|c|c|c|}
\hline $39 / \mathrm{M}$ & 17.2 & 18.9 & 19.2 & 17.2 & 18 \\
\hline $25 / \mathrm{M}$ & 46.1 & 49.4 & 47.2 & 47.2 & 51.7 \\
\hline $28 / \mathrm{M}$ & 10.2 & 12 & 8.7 & 12.4 & 9.7 \\
\hline X+ S.E.M & $23.0+6.7$ & $26.3+7.4$ & $23.9+7.3$ & $25.6+6.7$ & $22.8+7.4$ \\
\hline
\end{tabular}

Group A: (samples 1-6) an increase in NKCA of at least $20 \%$ over the control value is achieved for both concentrations of the peptides studied, however, the stimulation is not significant $(p>0.05)$.

Group B: samples 7-11) mixed results are obtained

The group A contains the samples that present stimulation of $25 \%$ of the control value, in both concentrations of ME and BE. The group B collects the samples that are not or that present mixed results, both stimulated only by ME (sample 8), only by BE (sample 7 ), only by a concentration of the opioid studied (sample 11) or not stimulated by both peptides (samples 9 and 10). Although it was possible to divide the response to opioids into two groups, the stimulation achieved by group A did not turn out to be statistically significant with respect to the control ( $p>0.05)$.

\section{Binding sites in lymphocyte membranes}

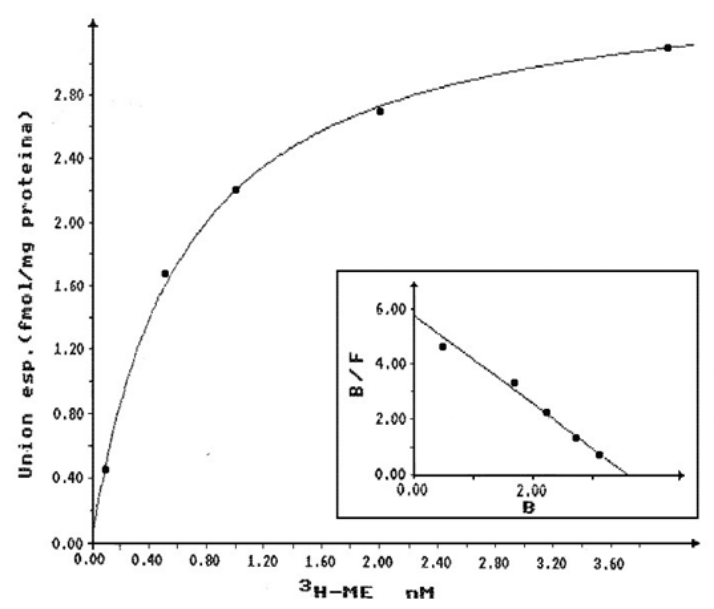

Graphic 2: Saturation curve and Scatchard plot (insert) for the binding of 3H-ME to HLM. Each value represents the average value of determinations in duplicate of three different samples.

Saturable specific binding curves reaching equilibrium in 30 minutes were obtained in $70 \%$ of the samples for both ligands (ME and Naloxone). Graphic 2 \& Graphic 3 show the saturation curve and the Scatchard plot (insert) for ME and Naloxone, respectively, when using radioligand concentrations between 1 and $40 \mathrm{nM}$. In both cases, the behavior agrees with the model of a single type of binding site described in the Scatchard analysis. The values of the parameters $\mathrm{K}_{\mathrm{D}}$ and $\mathrm{B}_{\max }$ obtained are shown in Table 2 .

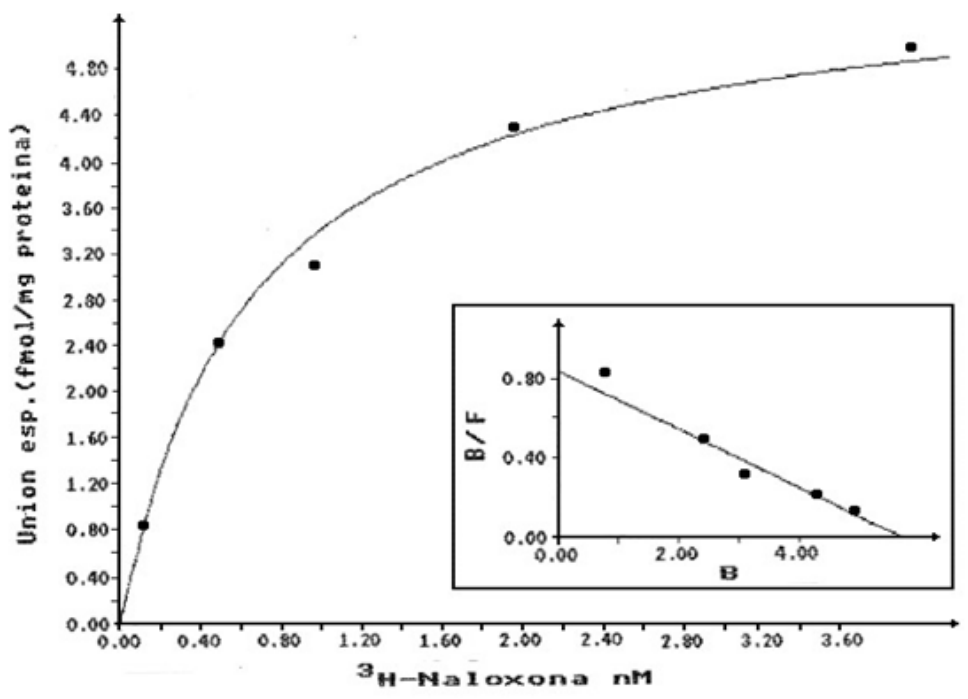

Graphic 3: Saturation curve and Scatchard plot (insert) for the binding of 3H-Naloxone to HLM. Each value represents the average value of determinations in duplicate of three different samples. 
Table 2: Values of the parameters KD [ $\mathrm{nm}$ ] and Bmax [fmol/mg protein] obtained in the Scatchard analysis. The parameters are very similar in both cases studied.

\begin{tabular}{|c|c|c|}
\hline Radioligando & KD \pm S.E.M & $\mathbf{B}_{\max } \pm$ S.E.M \\
\hline$\left({ }^{3} \mathrm{H}\right)-\mathrm{ME}$ & $6.8 \pm 0.35$ & $38 \pm 2.36$ \\
\hline$\left({ }^{3} \mathrm{H}\right)$-Naloxone & $5.9 \pm 0.23$ & $54 \pm 3.05$ \\
\hline
\end{tabular}

\section{Displacement of the union to membranes}

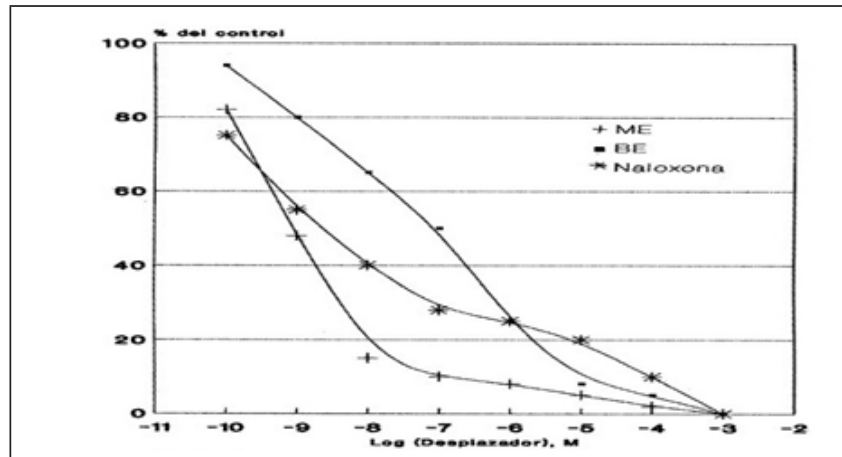

Graphic 4: Displacement curve of the binding of $3 \mathrm{H}-\mathrm{ME}$ to HLM mediated by ME, BE and Naloxone. Each value corresponds to the average of determinations in duplicate $(n=3)$.

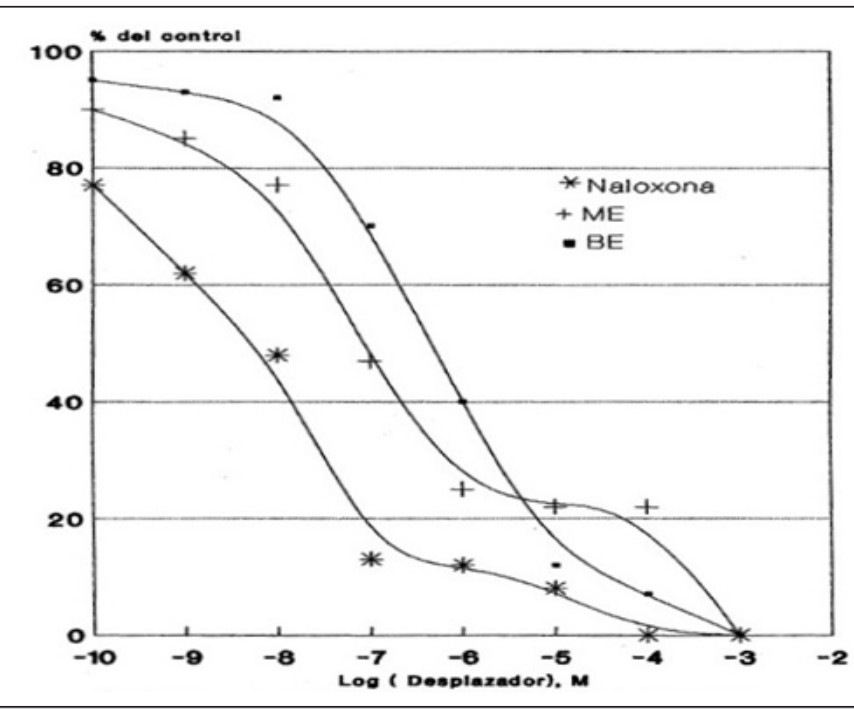

Graphic 5: Displacement curve of ${ }^{3} \mathrm{H}-\mathrm{Naloxone}$ binding to HLM mediated by ME, BE and Naloxone. Each value corresponds to the average of determinations in duplicate $(n=3)$.

Table 3: $\mathrm{IC}_{50}$ values for the displacement of $3 \mathrm{H}-\mathrm{ME}$ binding to HLM (Graphic 4).

\begin{tabular}{|c|c|}
\hline Desplazador & IC $_{\mathbf{5 0}}$ (nM) \\
\hline Metionina encefalina & 1 \\
\hline Naloxona & 3 \\
\hline B-Endorfina & 100 \\
\hline
\end{tabular}

Table 4: IC50 values for displacement of 3H-Naloxone binding to HLM (Graphic 5).

\begin{tabular}{|c|c|}
\hline Desplazador & IC $_{\mathbf{5 0}}(\mathbf{n M})$ \\
\hline Metionina encefalina & 7 \\
\hline Naloxona & 80 \\
\hline B-Endorfina & 500 \\
\hline
\end{tabular}

For the binding sites for ${ }^{3} \mathrm{H}-\mathrm{ME}$ and ${ }^{3} \mathrm{H}-\mathrm{Naloxone}$ a concentration of $20 \mathrm{nM}$ of the radioactive compound was used against a wide range of concentrations of Naloxone, $\mathrm{ME}$ and $\mathrm{BE}\left(10^{-10}\right.$ to $\left.10^{-2} \mathrm{M}\right)$. Thus, Graphic 4 \& Graphic 5 show the displacement of the total binding of ${ }^{3} \mathrm{H}-\mathrm{ME}$ and ${ }^{3} \mathrm{H}-\mathrm{Naloxone}$, respectively. Whereas Table 3 \& Table 4 present the $\mathrm{IC}_{50}$ values for both studies.

\section{Effect of Na+ and GTP ions}

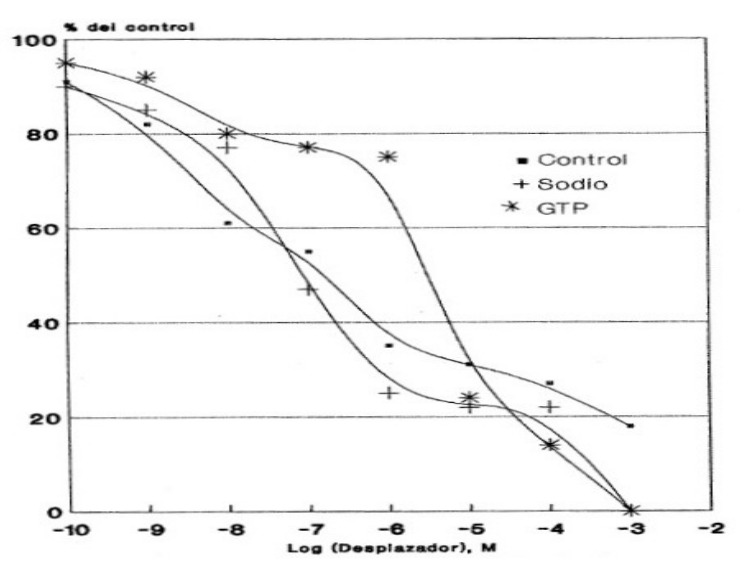

Graphic 6: Effect of sodium ions and GTP on the displacement of the binding of $3 \mathrm{H}-$ Naloxone in HLM, mediated by ME. Each value corresponds to the average of determinations in duplicate $(n=3)$.

The Graphic 6 shows the displacement in the case of ME, observing that the addition of GTP drastically decreases the ME junction to membranes, which is reflected in the $\mathrm{IC}_{50}$ value obtained: 88 times greater than that obtained in the absence of GTP. On the other hand, there was no noticeable change in the presence of sodium ions (Table 5).

Table 5: $\mathrm{IC}_{50}$ values for displacement of ${ }^{3} \mathrm{H}-$ Naloxone binding to $\mathrm{HLM}$ mediated by $\mathrm{ME}$, in the presence and absence of $\mathrm{NaCl}(100 \mathrm{mM})$ or GTP $(100 \mu \mathrm{M})$. (Graphic 6).

\begin{tabular}{|c|c|}
\hline Condition & IC $_{50}$ (nM) \\
\hline Control & 80 \\
\hline $\mathrm{Na}^{+}$ & 100 \\
\hline GTP & 7000 \\
\hline
\end{tabular}

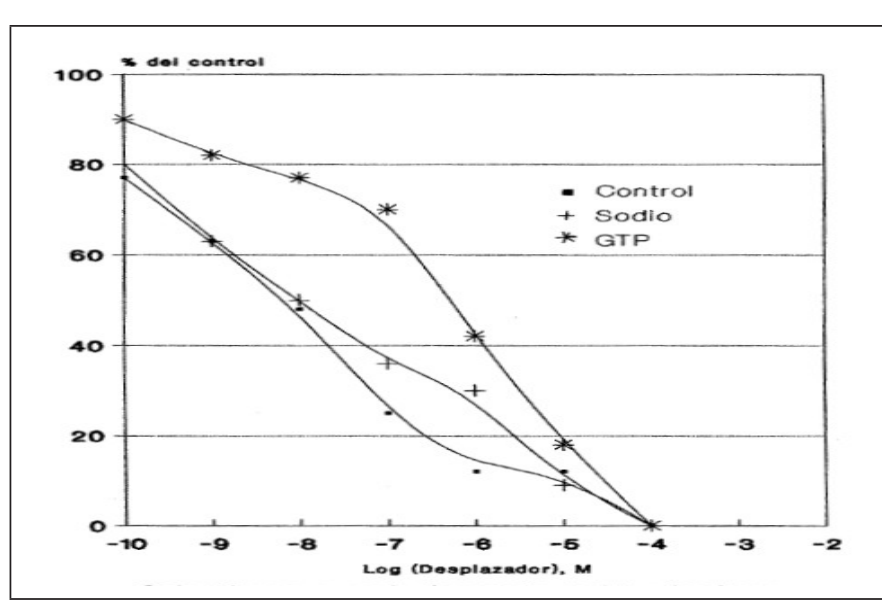

Graphic 7: Effect of $\mathrm{Na}^{+}$and GTP on the displacement of the binding of $3 \mathrm{H}-\mathrm{Nal}$ oxone to HLM, mediated by Naloxone. Each value corresponds to the average of determinations in duplicate $(n=3)$. 
The (Graphic 7) exhibits the displacement of the total ${ }^{3} \mathrm{H}-\mathrm{Nalox}-$ one binding mediated by Naloxone in the presence and absence of sodium or GTP ions.

The addition of GTP again drastically altered the displacement of Naloxone expressed in an $\mathrm{IC}_{50}$ value that was 85 times higher than that obtained in its absence. Finally, the addition of sodium ions did not alter the $\mathrm{IC}_{50}$ value obtained in its absence (Table 6).

Table 6: IC50 values for displacement of the $3 \mathrm{H}$-Naloxone binding to HLM by Naloxone, in the presence and absence of $\mathrm{NaCl}(100 \mathrm{mM})$ or GTP $(100 \mu \mathrm{M})$ (Graphic 7).

\begin{tabular}{|c|c|}
\hline Condition & IC $_{\mathbf{5 0}}(\mathbf{n M})$ \\
\hline Control & 7 \\
\hline $\mathrm{Na}^{+}$ & 10 \\
\hline $\mathrm{GTP}$ & 600 \\
\hline
\end{tabular}

\section{Discussion}

Since the discovery of OP and their endogenous ligands, it has been widely recognized that endogenous OP plays a variety of physiological roles $[28,40]$. Recently great importance has been given to the possibility that these peptides are involved in the modulation of the IS [41].

It has been shown that OP regulate NKCA $[17,42]$. NK cells have generated increasing interest due to their potential role in hematopoiesis and in the control of viral infections, as well as in the growth of some types of tumors and in the extracellular destruction of bacteria $[43,44]$. Although several agents capable of positively or negatively altering NKCA have been described, the mechanism by which this process develops is not completely clear. However, it is possible to divide it into stages: the first step of the lytic pathway involves the recognition of the target cell through receptor-ligand interactions. Next, signals from the target cell promote the activation of the secretory system of the NK cell and thus soluble factors such as NKCF are released to produce the final lysis of the target cell $[32,45,46]$. Numerous studies related to the NK cytolytic activity and its various modulators, however, not so much work aimed at determining or characterizing the receptors for these same agents. However, it has been described that both Naloxone and $\beta$-endorphin inhibit the binding of IL-2 to its receptor expressed in the lymphocyte membrane $[47,48]$ suggesting the participation or existence of opioid receptors or their analogues in immune cells. According to our results, when lymphocytes were incubated in physiological concentrations of ME $\left(10^{-10} \mathrm{M}\right)$ and $\mathrm{BE}\left(10^{-12} \mathrm{M}\right)[49,50]$, no response was obtained. similar in both cases studied. On the other hand, when the lymphocytes were treated with concentrations higher than the physiological ones, a response greater than $25 \%$ of the control value was obtained, even though this stimulation is not present in the total of the samples analyzed and no dependence was observed on the age or sex of the individual studied

Probably the individual diversity of the samples as well as to the high heterogeneity existing in the NK cells, since it has been described that they form at least three subpopulations of functionally distinct cells: effector cells capable of binding and destroying the target cell and two non-cytolytic subpopulations, one capable and the other incapable of joining the target cell $[43,51]$. Our results and the fact that Naloxone inhibits the increase in NKCA mediated by both IL- 2 and IFN- $\alpha[47,52]$ it would be expected to have the existence of opioid receptors in NK cells, both due to the stimulation achieved as per the relationship between OP and Naloxone. In support, the incubation of HML in the presence of ${ }^{3} \mathrm{H}-\mathrm{ME}$ or ${ }^{3} \mathrm{H}-\mathrm{Nalox}$ one shows, in $70 \%$ of the samples studied, high affinity saturation curves, indicating the presence of specific binding sites. located in the lymphocyte membrane. When performing the Scatchard analysis, a model corresponding to a type of binding site was verified in both ligands studied.

Because ME defines receptors of type $(\boldsymbol{\mu}, \boldsymbol{\delta})$ and Naloxone defines receptors of type ( $\boldsymbol{\mu}, \boldsymbol{\delta}$ and $\mathbf{k}$ ) [40,53], the existence of $\boldsymbol{\mu}$-type and $\boldsymbol{\delta}$-type opioid receptors in HLM is suggested. This agrees with the evidence of $\boldsymbol{\delta}$-type receptors in cells of the immune system and with the modulation of the immune response mediated by enkephalins, through $\boldsymbol{\mu}$-type and $\boldsymbol{\delta}$-type receptors [54,55]. Another important use of radioligand binding assays is its contribution to glimpse the molecular mechanism that couples the receptor-transducer-amplifier system with intracellular events. In radioligand binding studies, the binding of agonists and not that of antagonists is generally modulated by ions and nucleotides [56], Newton et al. Thus, there are numerous studies performed in neural tissues that have shown modulation of the receptor-ligand interaction by using $\mathrm{Na}^{+}$and GTP ions (or analogs) it being described that both markedly decrease the specific binding, using ligands that define receptors of the same type. type $\boldsymbol{\delta}$ and $\mathrm{k}$ as well as the type $\boldsymbol{\mu}$ and $\mathrm{k}[57,58]$.

When we are using GTP, observed an increase in the IC50 value and therefore suggests the participation of a protein with $G$ protein characteristics in the binding opioids and opiates to HLM. The $G$ protein participation has recently been confirmed, since a receptor- $\boldsymbol{\mu}$-opioid-G protein complex has been solubilised from membranes of tumor cells 7315 c, which retain the ability to bind agonists and the sensitivity to guanine nucleotides as they are subsequently reconstituted in phospholipid vesicles $[59,60]$. In general, a G protein associated with cell surface receptors is involved in the regulation of both receptor affinity and the effector system: adenylate cyclase. The binding of GTP to the G protein decreases the affinity of the receptor for agonists, promoting dissociation with the agonist and modulating the activity of the effector system $[33,55]$.

The modulation by $\mathrm{Na}^{+}$ions described in all the previous studies turned out to be of the same nature: a marked decrease in the specific binding is promoted, both individually as in conjunction with GTP analogues Gairin et al [61], suggesting that $\mathrm{Na}^{+}$probably occupies a different subunit within the membrane, which could function in conjunction with GTP to decrease the affinity of the binding. However, in this study a notorious alteration of the specific binding of the radioligand to its receptor was not detected when it was incubated in the presence of $\mathrm{Na}^{+}$ions, indicating that this ion does not affect the affinity of the binding, because it does not bind or not occupies the existing site in the membrane, proposed by the studies. The modulation of radioligand binding to its GTP-mediated receptor suggests that the binding sites for opioids detected in HLM are similar in molecular organization to those described in brain 
tissue and tumor cells in culture. The results obtained and presented in this Thesis suggest that cells of the IS may be susceptible to the action of OP present in the circulation, through receptors present in their membrane, although no direct relationship was detected between the existence of binding sites and stimulation of NKCA. That is, there was stimulation of NK cytolytic activity by these peptides both in the presence and in the absence of opioid receptors and in addition in other cases studied receptors were detected, but there was no stimulation by opioids.

Our results suggest some degree of similarity between the ME and Naloxone binding sites by the similarity between the KD and Bmax values obtained as well as by the reciprocal displacement of the membrane binding. This idea is reaffirmed when considering studies that indicate that although there are probably differences in the primary sequence of the receptors, these are products of the same gene, as has been described for the subtypes $\boldsymbol{\mu}$ and $\boldsymbol{\delta}$ [62-64]. It should be noted that these results refer to total peripheral lymphocytes. However, the described methodology allows us to deliver the necessary means to continue studies aimed at determining these parameters in fractions enriched in NK cells or in both human and murine NK cell lines.

\section{Conclusion}

The BE and ME opioid peptides stimulate NK cell-mediated cytolysis at higher than physiological concentrations. Human peripheral lymphocytes have binding sites with similar characteristics $\left(\mathrm{K}_{\mathrm{D}}\right.$ and $\mathrm{B}_{\max }$ ) for both ligands studied (ME and Naloxone). The binding of radioligands to these binding sites is affected by GTP, which suggests the participation of a type $\mathrm{G}$ protein protein. No direct relationship was observed between the stimulation of NKCA and the presence of binding sites for ME.

\section{References}

1. Herberman R (1986) Natural killer cells. Ann Rev Med 37: 347-352.

2. Vivier E, Raulet DH, Moretta A, Caligiuri M, Zitvogel L, et al. (2011) Innate or adaptive immunity? The example of natural killer cells. Science 331(6013): 44-49.

3. Kim JC, Choi J, Lee SJ, Lee YA, Jeon YM, et al. (2013) Evaluation of cytolytic activity and phenotypic changes of circulating blood immune cells in patients with colorectal cancer by a simple preparation of peripheral blood mononuclear cells. J Korean Surg Soc 85(5): 230-235.

4. Sarneva M, Vujanovic N, Van Der Brink M, Herbermen R, Hiserodt J (1989) Lymphocyte-activated killer cells in rat: generation of natural killer cells and lymphokine-activated killer cells from bone marrow progenitor cells. Cell Immunol 118(2): 448-457.

5. So EY, Park HH, Lee CE (2000) IFN- $\gamma$ and IFN- $\alpha$ Posttranscriptionally Down-Regulate the IL-4-Induced IL-4 Receptor Gene Expression. J Immunol 165 (10) 5472-5479.

6. Robertson M, Ritz J (1990) Biology and clinical relevance of human NK cells. Blood 76(12): 2421-2438.

7. Tarrio ML, Lee SH, Fragoso MF, Sun HW, Kanno Y, et al. (2014) Proliferation conditions promote intrinsic changes in NK cells for an IL-10 response. J Immunol193(1): 354-363.

8. Puente J, Maturana P, Miranda D, Navarro C, Wolf M, et al. (1991) Enhancemenet of human natural killer cell activity by opioid peptides: similar response to methionine enkephalin and $\beta$-endorphin. Brain behavior and Immunity 6(1): 32-39.
9. Stein C, Machelska H (2011) Modulation of Peripheral Sensory Neurons by the IS: Implications for Pain Therapy. Pharmacol Rev 63(4): 860-881.

10. Smith R, Grossman A, Gimson A, Besser G, Rees L (1985) Effect of liver and dysfunction on circulating met-enkephalin immunoreactivity. Neuroscience letter 60(3): 301-305.

11. Cawley NX, Li Z, Loh YP (2016) 60 years of POMC: Biosynthesis, trafficking, and secretion of pro-opiomelanocortin-derived peptides. J Mol Endocrinol 56(4): T77-T97.

12. Medback S, Cunnah D, Perry L, Ross G, Mason D, et al. (1987) Circulating met-enkephalin levels rise following insulin-induced hypoglycaemia in man. J Endocrinol p. 115.

13. Slominski AT, Zmijewski MA, Zbytek B, Brozyna A, Granese J, et al. (2010) Regulated proenkephalin expression in human skin and cultured skin cells. J Invest Dermatol 131(3): 613-622.

14. Boarder M, Mcardler W (1985) Opioid peptides in human adrenal: partial characterization and presence of adrenal peptide. J Clin Endocrinol 61(4): 658-665

15. Huber K, Brühl B, Guillemot F, Olson EN, Ernsberger U, et al. (2002) Development of chromaffin cells depends on MASH1 function. Development 129(20): 4729-4738.

16. Gach K, Wyrębska A, Fichna J, Janecka A (2011) The role of morphine in regulation of cancer cell growth. Naunyn Schmiedebergs Arch Pharmacol 384(3): 221-230.

17. Liang X, Liu R, Chen C, Ji F, Li T (2016) Opioid System Modulates the Immune Function: A Review. Transl Perioper Pain Med. 1(1): 5-13.

18. Prete P, Levin E, Pedram A (1986) The in vitro effects of endogenous opiates on natural killer cells, antigen-specific cytolitic T cells and T-cells subset. Exp Neurol 92(2): 349-359.

19. Shier P, Ngo K, Fung-Leung WP (1999) Defective CD8+ T Cell Activation and Cytolytic Function in the Absence of LFA-1 Cannot Be Restored by Increased TCR Signaling. J Immunol 163(9): 4826-4832.

20. Van Epps D, Kutvirt S (1987) Modulation of human neutrophil adherence by beta-endorphin and met-enkephalin. J neuroimmuno 15(3): 219-228.

21. Sharp B, Tsukayama D, Gekker G, Keane W, Peterson P (1987) Beta-endorphin stimulates human polymorphonuclear leukocytes superoxide production via a stereoselective opiate receptor. J Pharmacol Exp Therap 242(2): 579-582.

22. Liu Y, Shaw SK, Ma S, Yang L, Luscinskas FW, et al. (2004) Events Cell Surface Interactions and Signaling Regulation of Leukocyte. J Immunol 172: 7-13.

23. Prieto J, Subira M, Castilla A, Arroyo J, Serrano M (1989) Opioid peptides modulatethe organization of vimentin filaments, phagocytic activity and expression of Surface molecules in monocytes. Scand J Immunol 29(4): 391-398.

24. Reddy RC, Narala VR, Keshamouni VG, Milam JE, Newstead MW, et al. (2008) Sepsis-induced inhibition of neutrophil chemotaxis is mediated by activation of peroxisome proliferator-activated receptor-gamma. Blood 112(10): 4250-4258.

25. Kapitzke D, Vetter I, Cabot PJ (2005) Endogenous opioid analgesia in peripheral tissues and the clinical implications for pain control. Ther Clin Risk Manag 1(4): 279-297.

26. Al Hasani R, Bruchas MR (2011) Molecular mechanisms of opioid receptor-dependent signaling and behavior. Anesthesiology 115(6): 13631381.

27. Zagon I, Mclaughlin P (1988) Characterization of opioid binding sites in murine neurolastoma. Brain Res 449(1-2): 80-88.

28. Pasternack G (2013) Opioids and their receptors: Are we there yet? Neuropharmacology 76(Pt B): 198-203. 
29. Janeway CA, Travers P, Walport M (2001) Immunobiology: The IS in Health and Disease. 5th edition. New York: Garland Science. Interaction with self-antigens selects some lymphocytes for survival but eliminates others.

30. Parra D, Takizawa F, Sunyer JO (2013) Evolution of B cell immunity. Annu Rev Anim Biosci 1: 65-97.

31. Newman LC, Wallace DR, Stevens CW (2000) Selective opioid agonist and antagonist competition for [3H]-naloxone binding in amphibian spinal cord. Brain Res 884(1-2): 184-191.

32. Bonavida B (1988) Mechanism of Natural Killer cell-mediated cytotoxicity. Ann Rev NY Acad Sci 532: 336-340.

33. Ovadia H, Nitsan P, Abramsky O (1989) Characterization of opiate binding sites on membranes of rat lymphocytes. J neuroimmunol 21(2-3): 93-102.

34. Sharp BM (2006) Multiple opioid receptors on immune cells modulate intracellular signaling. Brain Behav Immun 20(1): 9-14.

35. Sacerdote P, Limiroli E, Gaspani L (2000-2013) Experimental Evidence for Immunomodulatory Effects of Opioids. In: Madame Curie Bioscience Database [Internet]. Austin (TX): Landes Bioscience.

36. Davies A, Lefkowitz R (1981) Corticosteid-induced differential regulation of $\beta$-adrenergic receptors in circulating human polymorphonuclear leukocytes and mononuclear leukocytes. J Clin Endocrinol Metabolism 51(3): 599-605.

37. Williams L, Snyderman R, Lefkowitz R (1976) Identification of $\beta$-Adrenergic receptors in human lymphocytes by $(-) 3 \mathrm{H}$-alprenolol binding. J Clin Invest 57(1): 149-155.

38. Lowry D, Rosebrough N, Farr A, Randall L (1951) Protein measurement with the Folin phenol reagent. J Biol Chem 193(1): 265-275.

39. Ogawa S, Masato F, Akitane M (1985) Effects of guanine nucleotides, transition metals and temperatura on enkephalin receptors of rat brain membranes. Peptides 6(Suppl 1): 23-28.

40. Feng Y, He X, Yang Y, Chao D, Lazarus LH, et al. (2012) Current research on opioid receptor function. Curr Drug Targets 13(2): 230-246.

41. Belkaid Y, Hand TW (2014) Role of the microbiota in immunity and inflammation. Cell 157(1): 121-141.

42. Boyadjieva NI, Sarkar DK (2010) Opioid-like activity of naltrexone on natural killer cell cytolytic activity and cytokine production in splenocytes: effects of alcohol. J Interferon Cytokine Res 30(1): 15-22.

43. Wang DM, Jiao X, Plotnikoff NP, Griffin N, Qi RQ et al. (2017) Killing effect of methionine enkephalin on melanoma in vivo and in vitro. Oncol Rep 38(4): 2132-2140.

44. Vivier E, Artis D, Diefenbach A, Di Santo J, Eberl G, et al. (2018) Innate Lymphoid Cell: 10 Years On. Cell 174(5): 1054-1066.

45. Glas R, Franksson L, Une C, Eloranta ML, Öhlén C, et al. (2000) Recruitment and activation of natural killer (NK) cells in vivo determined by the target cell phenotype. An adaptive component of NK cell-mediated responses. J Exp Med 191(1): 129-138.

46. Somanchi SS, McCulley KJ, Somanchi A, Chan LL, Lee DA (2015) A Novel Method for Assessment of Natural Killer Cell Cytotoxicity Using Image Cytometry. PLoS One 10(10): e0141074.
47. Kay N, Morley I, Allen J (1990) Interaction between endogenous opioids and IL-2 on PHA-stimulated human lymphocytes. Immunology 70(4): 485-491.

48. Tegeder I, Geisslinger G (2004) Opioids as Modulators of Cell Death and Survival-Unraveling Mechanisms and Revealing New Indications. Pharmacol Rev 56(3): 351-369.

49. Mosnaim A, Wolf M, Chevesich J, Callaghan O (1985) Plasma methionine-enkephalin levels. A biological marker for migrain? Headache 25(5): 259-261.

50. Vassou D, Bakogeorgou E, Kamp M, Dimitriou H, Hatzoglou A, et al. (2008) Opioids modulate constitutive B-lymphocyte secretion. International Immunopharmacology 8(5): 634-644.

51. Timares L, Bonavida B (1990) Purification and characterization of cytolytic and non-cytolytic human natural killer cell subsets. Proc Natl Acad Sci USA 87(16): 6063-6067.

52. Wang HY, Frankfurt M, Burns LH (2008) High-affinity naloxone binding to filamin a prevents mu opioid receptor-Gs coupling underlying opioid tolerance and dependence. PLoS One 3(2): e1554.

53. Wolleman M (1990) Recent developments in the research of opioid receptor subtype molecular characterization. J Neurochem 54(4): 10951101.

54. Ninković J, Roy S (2011) Role of the mu-opioid receptor in opioid modulation of immune function. Amino Acids 45(1): 9-24.

55. Sobczak M, Sałaga M, Storr MA, Fichna J (2013) Physiology, signaling, and pharmacology of opioid receptors and their ligands in the gastrointestinal tract: current concepts and future perspectives. J Gastroenterol 49(1): 24-45

56. Strange PG (2008) Agonist binding, agonist affinity and agonist efficacy at G protein-coupled receptors. Br J Pharmacol 153(7): 1353-1363.

57. Maguire JJ, Kuc RE, Davenport AP (2012) Radioligand binding assays and their analysis. Methods Mol Biol 897: 31-77.

58. Salahudeen MS, Nishtala PS (2016) An overview of pharmacodynamic modelling, ligand-binding approach and its application in clinical practice. Saudi Pharm J 25(2): 165-175.

59. Frey E, Gosse M, Cote T (1989) Reconstitution of the solubilized $\mu$-opioid receptor coupled to GTP-binding protein. Eur J Pharmacol 172(4-5): 347-356.

60. Hollmann M, Strumper D, Herroeder S, Durieux M (2005) Receptors, G Proteins, and Their Interactions. Anesthesiology 103(5): 1066-1078.

61. Rafay A, Majumdar S, Prakash B (2012) Exploring potassium dependent GTP hydrolysis in TEES family GTPases. FEBS Open Bio 2: 173-177.

62. Dietis N, Rowbotham DJ, Lambert DG (2011) Opioid receptor subtypes: fact or artifact? British Journal of Anaesthesia 107(1): 8-18.

63. McDonald J, Lambert DG (2015) Opioid receptors. BJA Education 5(1): 22-25.

64. Scatchard G (1949) The attraction of proteins for small molecules and ions. Ann NY Acad Sci 51: 660-672. 